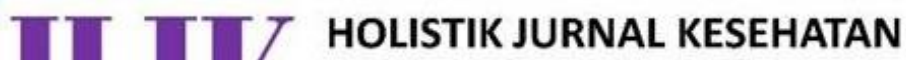 ISSN 1978-3337 (Print) ISSN 2620-7478 (Online)
}

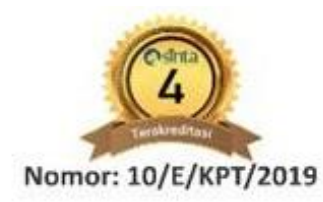

INFORMASI ARTIKEL

Received: August, 26, 2019

Revised: July, 16, 2021

Available online: July, 18, 2021

at : http://ejurnalmalahayati.ac.id/index.php/holistik

\section{Efektivitas pemberian temulawak dan madu terhadap peningkatan berat badan anak dengan status gizi kurang}

\author{
Linawati Novikasari*, Setiawati
}

Program Studi IImu Keperawatan, Universitas Malahayati.

Korespondensi Penulis: Linawati Novikasari *Email: Linawatinovikasari@malahayati.ac.id

\begin{abstract}
Additional curcuma xanthorrhiza and honey supplement to poor nutritional status in children
\end{abstract}

Background: Based on data from the Central Lampung Health Office in 2018, 2226 of children (24.7\%) finding malnourished. The results of the survey in 2019 of 15 children aged 4-5 years known (30\%) their weight were ungrown per three months. The communities rarely used plants and natural resources around them to improve nutrition for their children.

Purpose: To know effect of Additional curcuma xanthorrhiza and honey supplement to poor nutritional status in children.

Method: Quantitative research with Quasy Experimental case-control and using T-Test Paired. The population is children aged 1-3 years with poor nutritional status at Raja Basa Indah Public health center. Sampling technique with a ratio of 1: 1, of 40 participants divided into two groups such as intervention group and control group. The research instrument used an observation sheet. Research has taken 15 days, the ending by evaluation (participants measured with bodyweight scale).

Results: There was an increase in body weight in both groups, with a p-value of 0.003 (control group) and a pvalue of 0.000 (intervention group).

Conclusion: In the intervention group, the average weight gain was $0.66 \mathrm{Kg}$, while the control group had an average weight gain of $0.18 \mathrm{Kg}$. T-test with p-value 0.000 , the results show that the correlation of the treatment group is stronger than the control group

\section{Keywords: Curcuma xanthorrhiza; Honey; Supplement; Poor nutritional status; Children}

Pendahuluan: Berdasarkan data Dinas Kesehatan Lampung Tengah tahun 2018, sebanyak 2226 anak (24,7\%) ditemukan gizi buruk. Hasil survei tahun 2019 terhadap 15 anak usia 4-5 tahun diketahui (30\%) berat badannya tidak tumbuh per tiga bulan. Masyarakat jarang memanfaatkan tumbuhan dan sumber daya alam di sekitar mereka untuk meningkatkan gizi anak-anak mereka.

Tujuan: Untuk mengetahui efektivitas pemberian temulawak dan madu terhadap peningkatan berat badan anak dengan status gizi kurang di Puskesmas Raja Basa Indah Bandar Lampung.

Metode: Penelitian kuantitatif dengan Quasy Experimental case-control dan menggunakan T-Test Paired. Populasinya anak usia 1-3 tahun dengan status gizi buruk di Puskesmas Raja Basa Indah. Teknik pengambilan sampel dengan perbandingan 1:1, dari 40 partisipan dibagi menjadi dua kelompok yaitu kelompok intervensi dan kelompok kontrol. Instrumen penelitian menggunakan lembar observasi. Penelitian selama 15 hari dan diakhiri dengan evaluasi (partisipan diukur dengan timbangan badan).

Hasil: Pemberian Temulawak dan madu efekif dalam meningkatan berat badan pada anak dengan status gizi kurang pada kelompok kasus dan kontrol, dengan $p$-value 0,000 . 
Efektivitas Pemberian Temulawak dan Madu Terhadap Peningkatan Berat Badan Anak dengan Status Gizi Kurang

Simpulan: Pada kelompok intervensi, kenaikan rerata berat badan yaitu 0,660 , sedangkan pada kelompok kontrol pre-test dan posttest beberapa responden mengalami kenaikan berat badan dengan rerata 0,180 .hasil uji t-tes dengan nilai $p$-value 0,000 hasil penelitian ini menunjukkan bahwa kelompok perlakuan korelasinya lebih kuat dibandingkan kelompok kontrol.

\section{Kata Kunci: Temulawak (Curcuma xanthorrhiza); Madu, Berat badan; Anak; Status gizi kurang}

\section{PENDAHULUAN}

United Nations International Children's Emergency Fund (UNICEF) pada tahun 2015 memperkirakan sekitar 870 juta orang dari 7,1 miliar penduduk dunia menderita gizi buruk. Anakanak menjadi salah satu penderita gizi buruk terbesar di seluruh dunial. Lebih dari 70 persen kasus gizi buruk pada anak didominasi oleh Negara Asia, 26 persen di Afrika dan 4 persen di Amerika Latin serta Karibia. Setengah dari 10,9 juta kasus kematian anak didominasi kasus gizi buruk (United Nations International Children's Emergency Fund, 2015) Di Indonesia penurunan nafsu makan dialami oleh sekitar $25 \%$ pada usia balita. Penurunan nafsu makan ini akan berdampak pada penurunan asupan makanan dan dapat berakibat pada penurunan berat badan (Salam, 2010). Gizi kurang merupakan salah satu masalah gizi utama pada balita di Indonesia. Dari data koalisi untuk Indonesia sehat, dari tahun 2015-2016 dilaporkan balita dengan gizi kurang berjumlah dari 1.348.181 menjadi 1.528 .676 atau mengalami peningkatan sebesar 13,4\% (Kementerian Kesehatan Republik Indonesia, 2016; Diniyyah, \& Nindya, 2017). Balita dengan status gizi yang kurang $11,9 \%$ dan balita dengan gizi buruk sebesar 6,9\%. Masalah kesehatan masyarakat dianggap serius bila prevalensi BB/U berat-kurang antara 20,0 - 29,0 persen, dan dianggap prevalensi sangat tinggi bila $\geq 30$ persen (Kementerian Kesehatan Republik Indonesia, 2013).

Salah satu upaya penanggulangannya yaitu dilakukan secara terpadu dengan memberikan suplemen makanan multivitamin seperti pemberian temulawak dan madu. Temulawak mengandung zat kurkumin dan kurkuminoid (Batubara, \& Prastya, 2020). Kurkumin memiliki efek farmakologi sebagai antihepatoksik (mencegah liver), antioksidan, dan mengurangi tingkat kerusakan hati serta berfungsi sebagai detoksifikasi. Kurkumin dan kurkuminoid juga berfungsi sebagai kemopreventif (pencegahan) dan kuratif (penyembuhan) dalam melawan bibit kanker ( Prayudo, \& Novian, 2018). Selain itu, temulawak memiliki efek diuretic, penghilang nyeri sendi, meningkatkan nafsu makan (Gendrowati, 2018; Hidayat, \& Napitupulu, 2015). Madu memiliki kadar fruktosa dan glukosa yang tinggi sehingga mudah diabsorbsi oleh usus halus bersama zat-zat organik lainnya dan merangsang pencernaan bekerja lebih baik serta meningkatkan penyerapan makanan (Puspitasari, 2020). Penyerapan makanan yang baik dapat memicu nafsu makan. Sedangkan temulawak mengandung kurkuminoid dan minyak asiri yang membantu kinerja empedu dan pancreas sehingga penyerapan makanan di dalam usus lebih baik. Adanya peningkatan kerja dari empedu dan pankreas akan meningkatkan proses pencernaan makanan. Kombinasi dari madu dan temulawak akan meningkatkan khasiat keduanya dalam meningkatkan nafsu makan (Renny, Arief, \& Armini, 2010).

Berdasarkan data yang didapatkan dengan membandingkan 3 Puskesmas yang memiliki persentase balita ditimbang naik berat badannya dengan persentase terendah, yaitu Puskesmas Rajabasa Indah sebesar 2226 anak (61.06\%), pada posisi ke dua yaitu Puskesmas Palapa sebanyak 1561 anak (63.04\%) dan Puskesmas Kota Karang sebanyak 1219 anak (69.39\%). Hasil prasurvey 04 Juli 2020 dari 10 anak usia 1-3 tahun diketahui bahwa 7 anak (70\%) tidak mengalami kenaikan berat badan dan dari 10 anak tersebut 7 ibu $(70 \%)$ tidak tahu manfaat dari konsumsi madu temulawak untuk meningkatkan berat badan anak (Dinas Kesehatan Provinsi Lampung, 2018).

\section{METODE}

Jenis penelitian kuantitatif dengan rancangan menggunakan desain Quasi Experimental dan pendekatan one group pre test-post test pada kelompok case control. populasinya seluruh anak usia 1-3 tahun dengan status gizi kurang di wilayah

\section{Linawati Novikasari*, Setiawati}

Program Studi llmu Keperawatan, Universitas Malahayati.

Korespondensi Penulis: Linawati Novikasari *Email: Linawatinovikasari@malahayati.ac.id

DOI: https://doi.org/10.33024/hjk.v15i2.1666 
Efektivitas Pemberian Temulawak dan Madu Terhadap Peningkatan Berat Badan Anak dengan Status Gizi Kurang

kerja Puskesmas Raja Basa Indah Bandar Lampung. Sampel dalam penelitian ini 1:1 berjumlah 40 orang yang dibagi ke dalam 2 kelompok yaitu 20 kelompok intervensi dan 20 kelompok kontrol. Pemberian Temulawak dan madu yang diberikan kepada responden selama 2 minggu (15 hari) setiap 2 kali sehari di pagi dan sore hari sebelum makan. Pemberian madu sebanyak 1 sendok makan dan 250 gram temulawak yang diparut dan diambil sarinya kemudian dicampukan $1 / 2$ gelas air/susu (125 cc). Sedangkan pada kelompok kontrol tidak diberikan temulawak dan madu. Data diambil dengan dengan alat ukur lembar obsevasi kemudian peneliti mengolah data, melakukan uji normalitas untuk mengetahui apakah data tersebut berdistrbusi normal atau tidak. Pada data berdistribusi normal maka uji nya menggunakan uji $\mathrm{t}$ test dependent sedangkan jika data tidak berdistribusi normal maka uji yang digunakan menggunakan uji non parametrik dengan uji wilcoxon. Penelitian ini sudah lulus kelaikan etik dari Komisi Etik Penelitian Kesehatan (KEPK) Universitas Malahayati. Nomor Surat No.1424/EC/KEPUNMAL/IX/2019

\section{HASIL}

Tabel 1. Data Demografi Responden dan Hasil Evaluasi Intervensi

\begin{tabular}{|c|c|c|}
\hline Responden & $\begin{array}{c}\text { Intervensi } \\
(\text { Temulawak + Madu) } \\
n=20\end{array}$ & $\begin{array}{c}\text { Kontrol } \\
\text { (Tanpa Tambahan) } \\
n=\mathbf{2 0}\end{array}$ \\
\hline $\begin{array}{l}\text { Data Demografi Usia } \\
\text { (Mean +SD) (Rentang) (Tahun) }\end{array}$ & $\begin{array}{c}(1.85 \pm 0.74) \\
(1-3)\end{array}$ & $\begin{array}{c}(2.10 \pm 0.91) \\
(1-3)\end{array}$ \\
\hline \multicolumn{3}{|l|}{ Jenis Kelamin (n/\%) } \\
\hline Laki-laki & $11 / 56.8$ & $10 / 50.8$ \\
\hline Perempuan & $9 / 43,2$ & $10 / 49.2$ \\
\hline \multicolumn{3}{|l|}{ Sosial Ekonomi (n/\%) } \\
\hline Pendapatan sangat tinggi & $3 / 20.4$ & $2 / 10.5$ \\
\hline Pendapatan tinggi & $4 / 18.3$ & $4 / 15.5$ \\
\hline Pendapatan sedang & $7 / 35.7$ & $9 / 49.0$ \\
\hline Pendapatan rendah & $6 / 20.6$ & $6 / 25.0$ \\
\hline \multicolumn{3}{|l|}{ Urutan Anak (n/\%) } \\
\hline Sulung & $5 / 22.6$ & $6 / 32.2$ \\
\hline Tengah & $8 / 42.0$ & $6 / 32.2$ \\
\hline Bungsu & $7 / 35.4$ & $8 / 35.6$ \\
\hline \multicolumn{3}{|l|}{ Jumlah Saudara (n/\%) } \\
\hline $1-3$ & $14 / 62.4$ & $10 / 48.7$ \\
\hline$>4$ & $6 / 37.6$ & $10 / 51.3$ \\
\hline \multicolumn{3}{|c|}{$\begin{array}{l}\text { Evaluasi } \\
\text { Peningkatan Berat Badan (Mean +SD) } \\
\text { (Rentang) }\end{array}$} \\
\hline Sebelum & $(8,75 \pm 1,28)(7,0-10,8)$ & $(8,71 \pm 1,31)(7,0-10,9)$ \\
\hline Sesudah & $(9,41 \pm 1,39)(7,5-11,9)$ & $(8,89 \pm 1,24)(7,2-10,9)$ \\
\hline
\end{tabular}

Linawati Novikasari*, Setiawati

Program Studi llmu Keperawatan, Universitas Malahayati.

Korespondensi Penulis: Linawati Novikasari *Email: Linawatinovikasari@malahayati.ac.id

DOI: https://doi.org/10.33024/hjk.v15i2.1666 
Efektivitas Pemberian Temulawak dan Madu Terhadap Peningkatan Berat Badan Anak dengan Status Gizi Kurang

Hasil analisis tabel 1, diketahui pada kelompok intervensi bahwa peningkatan berat badan sebelum pemberian temulawak dan madu pada 20 anak, dengan mean 8,75 standar deviasi 1,28 standar eror 0,2856 dan nilai min-max 7,0-10,8. Peningkatan Berat Badan Sesudah pemberian temulawak dan madu pada 20 anak dengan mean 9,41 standar deviasi 1,31 dengan standar eror 0,31017 dan nilai min-max 7,5-11,9 sedangkan pada kelompok kontrol sebelum dengan mean 8,71 standar deviasi 1,30274 dengan standar eror 0,2913 dan nilai min-max 7,0-10,9 dan kontrol sesudah dengan mean 8,895 standar deviasi 1,24371 standar eror 0,2781 dan nilai $\min -\max 7,2-10,9$.

Tabel 2. Efektivitas Pemberian Temulawak dan Madu

\begin{tabular}{cccccc}
\hline Variabel & N & SE & $\begin{array}{c}\text { Selisih } \\
\text { Mean }\end{array}$ & S.D & P - value \\
\hline intervensi & 20 & 0,04724 & 0,66 & 0,21126 & 0.000 \\
kontrol & 20 & 0,05058 & 0,18 & 0,22618 & 0.000 \\
\hline
\end{tabular}

Hasil analisis tabel 2, bahwa perbedaan hasil pengukuran terhadap 20 responden untuk melihat Efektifitas peningkatan berat badan sebelum diberikan temulawak dan madu dengan kelompok intervensi SE 0,04724 selisih mean 0,66 SD 0,21126 sedangkan kelompok kontrol SE 0,050508 selisih mean 0,18 SD 0,22618 dengan nilai $p$-value 0,000 yang artinya pemberian temulawak dan madu efektif terhadap peningkatan berat badan pada anak.

\section{PEMBAHASAN}

Dari tabel 1 diketahui bahwa peningkatan berat badan sebelum pemberian temulawak dan madu pada 20 anak, kelompok intervensi sebelum dengan mean 8,750 standar deviasi 1,2771 standar eror 0,2856 dan nilai min-max 7,0-10,8. Peningkatan Berat Badan Sesudah pemberian temulawak dan madu pada 20 anak dengan mean 9,4100 standar deviasi 1,31017 standar eror 0,31017 dan nilai min-max 7,5-11,9 sedangkan pada kelompok kontrol sebelum dengan mean 8,715 standar deviasi 1,30274 standar eror 0,2913 dan nilai min-max 7,0-10,9 dan kontrol sesudah dengan mean 8,895 standar deviasi 1,24371 standar eror 0,2781 dan nilai min-max 7,2-10,9

Berat badan menjadi ukuran antropometri yang terpenting pada masa bayi dan balita. Saat ini berat badan dipakai sebagai indikator yang terbaik untuk mengetahui keadaan gizi dan tumbuh kembang anak karena jika terdapat perubahan dalam pengukuran objektif dapat diulangi (Dewi, Soetjiningsih, \& Prawirohartono, 2011). Temulawak mengandung zat kurkumin dan kurkuminoid. Kurkumin memiliki efek farmakologi sebagai antihepatoksik (mencegah liver), antioksidan, mengurangi tingkat kerusakan hati, diuretic, penghilang nyeri sendi, dan meningkatkan nafsu makan. Kurkumin dan kurkuminoid juga berfungsi sebagai detoksifikasi, kemopreventif (pencegahan), dan kuratif (penyembuhan) dalam melawan bibit kanker (Gendrowati, 2018).

Madu memiliki kandungan fruktosa (sekitar $38,5 \%$ ) dan glukosa (sekitar 31,0\%) (Syarif, 2020). Sehingga mirip dengan sirup gula sintetis yang diproduksi terbalik, sekitar $48 \%$ fruktosa, glukosa $47 \%$, dan sukrosa $5 \%$. Sebagian besar madu mengandung gula dan hanya mengandung sedikit jumlah vitamin atau mineral (Sakri, 2012). Madu memiliki bermanfaat untuk memenuhi kebutuhan gizi anak-anak, meningkatkan daya tahan tubuh pada anak - anak, memulihkan kesehatan setelah sembuh dari sakit atau operasi, dan merangsang nafsu makan (Khomsan \& Anwar, 2008). Pemberian temulawak dan madu secara bersamaan kepada anak secara teratur dapat meningkatkan nafsu makan pada anak, sehingga dengan meningkatnya nafsu makan, maka anakanak akan mengalami kenaikan berat badan (Utami, \& Heli, 2015).

Madu mengandung kadar fruktosa dan glukosa yang cukup tinggi sehingga madu dapat langsung diserap tanpa harus merubahnya menjadi bentuk gula yang lebih sederhana. Gula yang ada dalam madu ini dapat diserap dengan mudah oleh tubuh (Septiana, Handayani, \& Winarsi, 2019). Temulawak mengandung zat yang bagus untuk pencernaan, apabila pencernaan dalam tubuh

\section{Linawati Novikasari*, Setiawati}

Program Studi llmu Keperawatan, Universitas Malahayati.

Korespondensi Penulis: Linawati Novikasari *Email: Linawatinovikasari@malahayati.ac.id

DOI: https://doi.org/10.33024/hjk.v15i2.1666 
Efektivitas Pemberian Temulawak dan Madu Terhadap Peningkatan Berat Badan Anak dengan Status Gizi Kurang

bekerja dengan baik maka nutrisi akan lebih mudah diserap oleh tubuh (Masita, 2020). Jika pencernaan baik, nafsu makan meningkat maka anak-anak akan lebih mudah memakan semua jenis makanan yang disukai. Hal ini dapat meningkatkan berat badan pada anak.

Dari tabel 2 terlihat bahwa perbedaan hasil pengukuran terhadap 20 responden untuk melihat efektifitas peningkatan berat badan sebelum diberikan temulawak dan madu dengan kelompok intervensi SE 0,04724 selisih mean 0,66 SD 0,21126 sedangkan kelompok kontrol SE 0,050508 selisih mean 0,18 SD 0,22618 dengan nilai $p$-value 0,000 yang artinya pemberian temulawak dan madu efektif terhadap peningkatan berat badan pada anak.

Temulawak berkhasiat mengobati asma, nyeri pinggang, mengobati maag, mengatasi sakit kepala, sakit perut, serta sebagai suplemen peningkat nafsu makan bagi anak-anak. Kandungan minyak atsiri temulawak yang bernama xanthorrhizol menjadi sumber suplemen peningkat nafsu makan. Minyak atsiri temulawak dapat terjadi karena sifat koleretiknya, yaitu mempercepat pengosongan lambung serta pencernaan dan absorpsi lemak di usus, kemudian mensekresi berbagai hormon yang meregulasi peningkatan nafsu makan, Selan itu, fungsi madu secara umum adalah memenuhi kebutuhan gizi anak-anak yang makanannya tidak mencukupi untuk pertumbuhan secara normal,meningkatkan daya tahan tubuh pada anak - anak, memulihkan kesehatan setelah sembuh dari sakit/operasi, merangsang nafsu makan (Gendrowati, 2018; Badan Pengawas Obat, 2020).

Data berat pre dan post test pada kelompok perlakuan, kenaikan rerata berat badan yaitu 320 gram. Pada kelompok kontrol pada pre-test rerata berat badan 9380 gram dan pada posttest beberapa responden mengalami kenaikan berat badan dengan rerata 9420 gram. Rerata kenaikan berat badan dari pra dan pasca yaitu 40 gram. hasil uji t-tes dengan nilai $p$-value 0,000 dengan hasil menunjukkan bahwa kelompok perlakuan korelasinya sangat kuat dibandingkan kelompok kontrol, keadaan ini menunjukkan bahwa masukan nutrisi pada kelompok perlakuan lebih baik daripada kelompok kontrol. Hasil tersebut diperkuat dengan hasil uji statistik independent $t$ - test yang menunjukkan bahwa ada perbedaan rata-rata berat badan antara yang diberi madu temulawak dan yang tidak diberi madu temulawak (Renny, Arief, \& Armini, 2010).

Menurut analisa peneliti adanya peningkatan berat badan anak dengan status gizi kurang yang mendapat treatmen dengan memberikan temulawak dan madu mengalami peningatan karena temulawak mengandung minyak atsiri yang dapat meningkatkan nafsu makan. Sehingga anak akan menyukai makanannya dan pada akhirnya berat badan anak menjadi naik. Sedangkan pada kelompok kontrol yang tidak diberi treatmen berat badan anak dapat naik dikarenakan adanya program pemberian makanan tambahan dari puskesmas sehingga kebutuhan gizi anak terpenuhi dan berat badan anak dapat naik. Namun peningkatan berat badan ini lebih banyak pada kelompok case yg diberikan temulawak dan madu artinya temulawak dan madu berpengaruh terhadap peningakatan berat badan pada anak.

\section{SIMPULAN}

penelitian ini menunjukkan bahwa kelompok perlakuan korelasinya lebih kuat dibandingkan kelompok kontrol. Diperkuat dengan hasil uji statistik independent t-test yang menunjukkan bahwa ada perbedaan rata-rata berat badan antara yang diberi madu temulawak dan yang tidak diberi madu temulawak.

\section{DAFTAR PUSTAKA}

Badan Pengawas Obat. (2020). Pedoman Penggunaan Herbal dan Suplemen Kesehatan dalam Menghadapi COVID-19 di Indonesia. Jakarta: BPOM RI.

Batubara, I., \& Prastya, M. E. (2020). Potensi Tanaman Rempah dan Obat Tradisional Indonesia Sebagai Sumber Bahan Pangan Fungsional. In Seminar Nasional Lahan Suboptimal (No. 1, pp. 24-38).

Dewi, N. N., Soetjiningsih, P. P., \& Prawirohartono, E. P. (2011). Effect of massage stimulation on weight gain in full term infants. Paediatrica Indonesiana, 51(4), 202-6.

\section{Linawati Novikasari*, Setiawati}

Program Studi llmu Keperawatan, Universitas Malahayati.

Korespondensi Penulis: Linawati Novikasari *Email: Linawatinovikasari@malahayati.ac.id 
Efektivitas Pemberian Temulawak dan Madu Terhadap Peningkatan Berat Badan Anak dengan Status Gizi Kurang

Dinas Kesehatan Kota Bandar Lampung. (2018). Kejadian Status Gizi Buruk Pada Anak.

Diniyyah, S. R., \& Nindya, T. S. (2017). Asupan energi, protein dan lemak dengan kejadian gizi kurang pada balita usia 24-59 bulan di Desa Suci, Gresik. Amerta Nutrition, 1(4), 341-350.

Gendrowati, W. (2018). Tanaman Ajaib. Jakarta Timur: Pustaka Makmur.

Hidayat, I. R. S., \& Napitupulu, R. M., (2015). Kitab tumbuhan obat. Agriflo.

Kementerian Kesehatan Republik Indonesia. (2014). Panduan gizi seimbang. Jakarta. Kemenkes RI. Diakses dari: https://www.academia.edu/25314413/Pedoman Gizi Seimbang oleh kemenkes.

Kementerian Kesehatan Republik Indonesia. (2013). Riset Kesehatan Dasar 2013. Jakarta: Kementerian Kesehatan RI. Diakses dari: http://kesga.kemkes.go.id/images/pedoman/Dat a\%20Riskesdas \%202013.pdf

Khomsan, I. A., \& Anwar, I. F. (2008). Sehat itu mudah. Hikmah

Masita, N. (2020). Penambahan Jamu Herbal dan Vitamin terhadap Profil Organ dalam Ayam Kampung Unggul Balitnak (KUB) (Doctoral dissertation, Universitas Islam Negeri Alauddin Makassar).

Prayudo, A. N., \& Novian, O. (2018). Koefisien transfer massa kurkumin dari temulawak. Widya Teknik, 14(1), 26-31.

Puspitasari, L. (2020). Kreasi dan Inovasi COMUT (Coklat Temulawak Imut) Penambah Nafsu Makan. Jurnal ABDIMAS-HIP: Pengabdian Kepada Masyarakat, 1(2), 88-93.
Renny, F., Arief, Y. S., \& Armini, N. K. A. (2010). Curcuma and Honey Increases Body Weight of Toddler. Jurnal Ners, 5(1), 49-54.

Sakri, F. M. (2012). Madu dan khasiatnya: Suplemen sehat tanpa efek samping. Diandra Kreatif.

Salam, A. (2010). Faktor risiko kejadian obesitas pada remaja. Hasanuddin University.

Septiana, A. T., Handayani, I., \& Winarsi, H. (2019). Aktivitas antioksidan dan sifat fisikokimia madu temulawak (curcuma zanthorrhiza roxb) yang ditambah ekstrak jahe (zingiber officinale rosc). Jurnal Aplikasi Teknologi Pangan, 8(4), 155-160.

Syarif, S. (2020). Efektifitas Pemberian Kombinasi Jus Bayam, Sunkist, Madu Terhadap Peningkatan Kadar Haemoglobin Pada lbu Hamil Anemia Di Puskesmas Dahlia Kota Makassar. Jurnal Antara Kebidanan, 3(1), 6976.

United Nations International Children's Emergency Fund. (2015). Status Gizi Anak. https://www.unicef.org/indonesia/? gac=1.2041 39172.1623336900.EAlalQobChMlq_3DkKmN 8QIVvpVLBR2KfgBJEAMYASAAEgLn7fD BwE

Utami, W. T., \& Heli, A. S. K. (2015). Effect of Vitamins, Honey and Temulawak on the Appetite Improvement of Children Age 2 Years in Sembung Sukorame Lamongan. Asuhan Kesehatan: Jurnal IImiah IImu Kebidanan dan Keperawatan, 6(2).

\section{Linawati Novikasari*, Setiawati}

Program Studi llmu Keperawatan, Universitas Malahayati.

Korespondensi Penulis: Linawati Novikasari *Email: Linawatinovikasari@malahayati.ac.id

DOI: https://doi.org/10.33024/hjk.v15i2.1666 